Jurnal Keperawatan Padjadjaran /Padjadjaran Nursing Journal

ISSN 2338-5324 (print)

ISSN 2442-7276 (online)

Online di http://jkp.fkep.unpad.ac.id

DOI : $10.24198 / \mathrm{jkp}$

\title{
Relationship between Quality of Nursing Work Life with Nurse Job Satisfaction in Pilot Project of Nurse Clinical Career Implementation
}

\author{
Ineke Patrisia ${ }^{1}$,F. Sri Susilaningsih ${ }^{2}$, Kurniawan Yudianto ${ }^{2}$ \\ ${ }^{1}$ Universitas Pelita Harapan, ${ }^{2}$ Faculty of Nursing, Universitas Padjadjaran \\ Email:inekepatrisia@gmail.com
}

Submitted: 7-8-2017 Accepted: 30-4-2018 Published:30-4-2018

\begin{abstract}
Quality of nursing work life plays an important role and must be considered by a hospital organization for the achievement of nurse job satisfaction. The career ladder is one source of satisfaction and will impact on service quality. The research method used correlational analysis with cross sectional approach. The total samples in this study as many as 193 people. In general, the results showed that most of the respondents $(98.4 \%)$ had a high quality of nursing work life and when viewed from career level category it was found that all clinical nurses $4(100 \%)$ had high quality of work life and clinical nurses $1-3(97.9 \%, 98.4 \%, 98.7 \%)$ most of respondents have high quality of work life. The results also showed that in general, most of respondents $(79.3 \%)$ had nurses' job satisfaction and when viewed from career level category it was found that most of clinical nurses $1-4(77.1 \% ; 80.3 \%$; $83.3 \%$; $79.5 \%$ ) were satisfied with their work. Indicators in the nurse's job satisfaction are the main priorities in the aspects of compensation, working conditions, recognition, independence. Indicators that need to be maintained by the management of Hasan Sadikin General Hospital Bandung are supervision technical, moral values, responsibility, advancement, coworkers. The correlation between quality of nursing work life variable with nurse's job satisfaction is weak, significant and unidirectional in the pilot project implementation of clinical nurse career ladder in Hasan Sadikin General Hospital Bandung. Researchers expect the results of this study can be used as an evaluation for nursing management of Hasan Sadikin General Hospital Bandung. Further research is expected to be able to identify the relationship between the dimensions of the quality of nursing work life with the indicators of nurse's job satisfaction.
\end{abstract}

Keywords: Career ladder, job satisfaction, QNWL. 
Ineke Patrisia : Relationship between Quality of Nursing Work Life with Nurse Job Satisfaction

\section{Introduction}

Things that must be observed by the hospital which is related to problem that arise or that will appear. One of the problems that can not be avoided by a hospital is when the nurse wants to leave the hospital. This is often happened by various hospitals especially when it is done by staff who potentially and most contribute to the progress and service system. The problem arises one of them due to lack of ownership and attachment. The sense of attachment and belonging to hospital services is important because it can increase staff loyalty within the hospital. Because, when staff feel attached and possessed, the staff will give a part of himself totally and understand and help in achieving the goals to be achieved by a hospital. Faced with this, Cascio (2008) looked at ways to create productive human resources, quality, commitment and dedication to work is to pay attention and maintain the quality of working life. An ongoing process whereby each individual continually strives to build relationships with his work environment is called work adjustment. When a person enters the work environment for the first time, his/ her behavior leads to the fulfillment of his needs, and he/she will also feel the rewards given by his work environment. If he/she can have a relationship with his/her work environment then he/she will try to defend it. However, if he does not find the relationship, he will try to build that relationship and if it fails it will lead to his leaving the job. When an individual is able to fulfill the requirements of his or her working environment it can be regarded as a satisfactory worker, and if his/ her working environment is able to meet the needs of an individual, he can be said to be a satisfied worker (Vidiasta, 2010). Where the existence of this source of satisfaction is not always a factor raises satisfaction but if one of these factors does not exist then the nurse will be dissatisfied. The second factor is the motivator where if the factors exist then it will form a strong motivation so that the quality of work for the better. Examples are recognition, career enhancement and others.

The Implementation of pilot project of clinical nurse career implementation at Dr. Hasan Sadikin Bandung started from line based survey conducted by Susilaningsih, Kurniawan, Somantri, \& Yudianto (2013) related to Quality of Work Life Nurse, Quality of Care and Patient Pre-Implementation Satistication of Career Nurse Pattern in Education Hospital.

Based on the results of interviews in January 2017 conducted in the Nursing Committee Committee RSHS, recognized by the Head of Nursing Special Services RSUP Dr. Hasan Sadikin Bandung section, on the implementation of the current nursing career path, it seemes that the development of CPD (Continues Personal Development) is adjusted with the competence in the career path in accordance with the work area of the nurse, the implementation is adjusted to the competency gap of the assessment result and adjusted to the condition and the ability of RSHS. The clinical nurses feel that space is provided in the pilot project of this career path to develop themselves and improve their clinical competence. So that the researcher feel important to do evaluation to same research sample by doing research of relationship between quality of nursing work life with nurse job satisfaction in pilot project of nurse clinical career implementation in RSUP. Dr. Hasan Sadikin Bandung.

\section{Method}

This research used quantitative research with correlational analysis method with research approach using cross sectional. The sample used consisted of 193 people. The sampling technique used was purposive sampling. The selection of samples was based on certain characteristics (PK 1-4) which were deemed to have a close connection with previously known population characteristics that had followed the implementation of the clinical nurse career path during the period of implementation of the career path implementation pilot project $(>2$ years of service) in the inpatient medical surgical and interne ward. .

\section{Result}

1) Quality of Nurse Work life 
Ineke Patrisia : Relationship between Quality of Nursing Work Life with Nurse Job Satisfaction

Table 1 QNWL Average Score

\begin{tabular}{lcccc}
\hline \multicolumn{1}{c}{ Dimention } & Median & Possible Range & Mean & Actual Range \\
\hline All dimention (42 item) & 105 & $42-168$ & 123.4 & $106-148$ \\
Work life/home life (7 item) & 17.5 & $7-28$ & 21.86 & $18-24$ \\
Work design (10 item) & 25 & $10-40$ & 27.61 & $25-35$ \\
Work context (20 item) & 50 & $20-80$ & 59.59 & $50-72$ \\
Work world (5 item) & 12.5 & $5-20$ & 14.31 & $13-17$ \\
\hline
\end{tabular}

Table 2 Quality of Frequency Distribution Nurse Work Life in General

\begin{tabular}{lcccc}
\hline \multirow{2}{*}{\multicolumn{1}{c}{ Dimention }} & \multicolumn{2}{c}{ High } & \multicolumn{2}{c}{ Low } \\
\cline { 2 - 5 } & F & \% & F & \% \\
\hline All dimention (42 item) & 190 & 98.4 & 3 & 1.6 \\
Work life/home life (7 item) & 189 & 97.93 & 4 & 2.07 \\
Work design (10 item) & 174 & 90.15 & 19 & 9.85 \\
Work context (20 item) & 183 & 94.82 & 10 & 5.18 \\
Work world (5 item) & 157 & 81.35 & 36 & 18.65 \\
\hline
\end{tabular}

Table 3 Quality of Nurse Work Life Based on Categories Level of Career Level

\begin{tabular}{ccccc}
\hline \multirow{2}{*}{ Career Level } & \multicolumn{3}{c}{ High } & \multicolumn{3}{c}{ Low } \\
\cline { 2 - 5 } & F & \% & F & \% \\
\hline PK 1 & 47 & 97.9 & 1 & 2.1 \\
PK 2 & 60 & 98.4 & 1 & 1.6 \\
PK 3 & 77 & 98.7 & 1 & 1.3 \\
PK 4 & 6 & 100 & 0 & 0 \\
\hline
\end{tabular}

Based on the calculation of the total dimensions obtained the actual range value 106-148 with a mean of 123.4 and the middle value of 105 so that it showed that the respondents had met the quality of working life. The overall mean value of the dimension was supported by the average value of each dimension that was all higher than the mean of each dimension.

If seen from the frequency distribution of respondents in general can be seen in the table below:

Based on table 2 illustrated that the respondents from the Kemuning Building and Fresia Building Dr. Hasan Sadikin Bandung almost all respondents had high quality of nurse work life (98.4\%). Looking from each dimension, almost all respondents had high quality of nurse work life.

Based on table 3 illustrated that based on career level, it appeared that respondents from PK I-3 almost all had high quality of work life. All nurses in PK 4 appeared to have a high quality of nursing work. This indicates that in general, almost all nurses from each level of career level feel that they have the quality of nurse work life.

2) Nurse Job Satisfaction

Based on the results of the research in table 4, nurses job satisfaction in Dr. Hasan Sadikin Bandung 79.3\% was satisfied, so that the level of job satisfaction nurses almost entirely satisfied.

\section{3) Cartesian Diagram of Job Satisfaction}

Based on the results of research as shown in table 5, there were 4 indicators located in this quadrant compensation, working conditions, recognition and independence.

Based on the results of research as shown in table 6 , there were 5 indicators located in this quadrant that was supervision technical, moral values, advancement, co workers, responsibility.

4) The Relationship between the Quality of 
Ineke Patrisia : Relationship between Quality of Nursing Work Life with Nurse Job Satisfaction

Table 4 Distribution of Nurse Job Satisfication Frequency

\begin{tabular}{lcc}
\hline \multicolumn{1}{c}{ Satisfication } & f & \% \\
\hline Satisfied & 153 & 79.3 \\
Not Satisfied & 40 & 20.7 \\
\hline
\end{tabular}

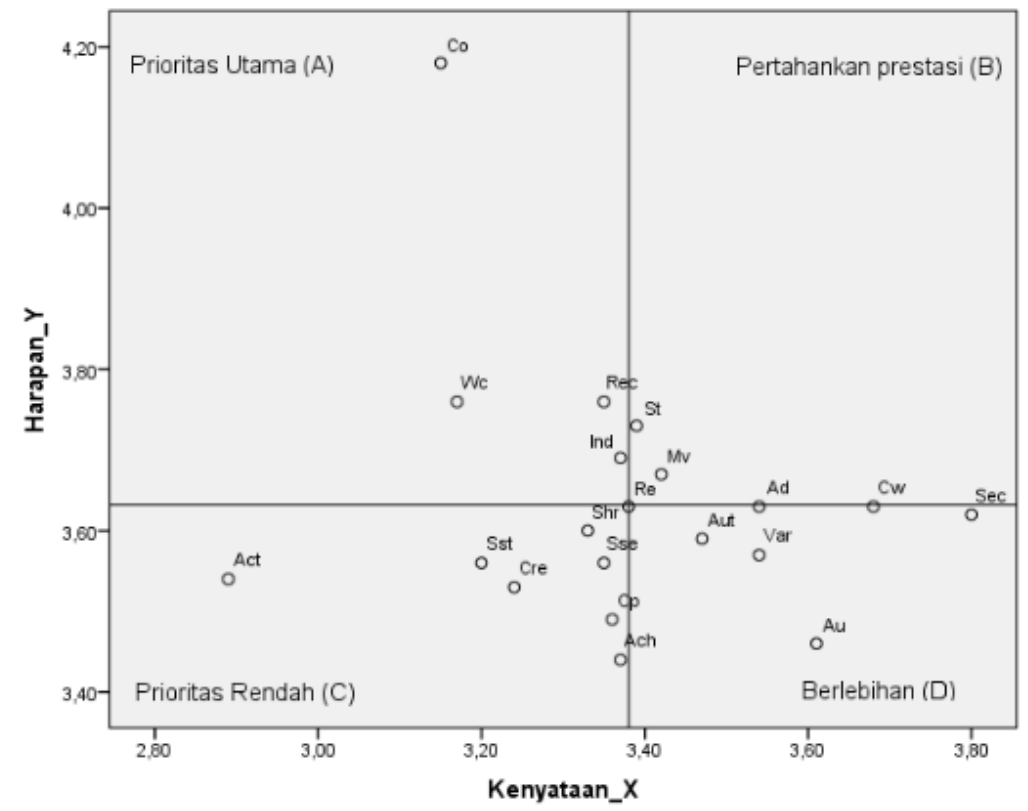

Diagram 1 Cartesian Diagram

Table 5 First Priority Indicator (Prioritas Utama)

\begin{tabular}{ll}
\hline \multicolumn{1}{c}{ Aspect } & \multicolumn{1}{c}{ Statement } \\
\hline Compensation & The salary I receive and the work I do \\
Working conditions & Working environment conditions such as room availability and work equipment \\
Recognition & The praise I got over work done \\
Independence & Opportunity to try my own method within doing work \\
\hline
\end{tabular}

Table 6 Indicators that Need to be Maintained (Pertahankan prestasi)

\begin{tabular}{ll}
\hline \multicolumn{1}{c}{ Aspect } & \multicolumn{1}{c}{ Statement } \\
\hline Supervision technical & My supervisor's competence in making decisions \\
Moral values & Be able to do things which is not contradictory with my consience \\
Responsibility & Freedom for using own self-assesment \\
Advancement & Opportunity for improvement in work \\
Co workers & Relationships interact with co-workers \\
\hline
\end{tabular}

Nurse Work Life with Nurse Job Satisfaction

The result of Spearman test is 0.246 with $p$-value 0.001 . It can be seen that the correlation value had a value of 0.246 which can be categorized as having a weak relationship and based on the significance test the result showed the value of 0.001 , which means the association of the two variables was significant. So it can be concluded that the relationship between the variable quality of nurse work life with nurse job satisfaction 
Ineke Patrisia : Relationship between Quality of Nursing Work Life with Nurse Job Satisfaction

was weak, significant and unidirectional. This means that when the variable value of the quality of work life of the nurse was high, then the variable value of nurse job satisfaction will be high also.

\section{Discussion}

1) Quality of Nurse Work life Generally and Based on Categories Career Level

Looking from the results of the research in table 1, it can be concluded that there was improvement of quality of work life after the implementation of nurse career level. This was evident from the increase in the average score of nurse job quality in 2013 which was 115.22 (based on survey line conducted by Susilaningsih, Kurniawan, Somantri, and Yudianto (2013)) to 123.4. Seeing from table 2 , there was an increase compared to the year of 2013 which is $47 \%$ (based on survey result conducted by Susilaningsih, Kurniawan, Somantri, and Yudianto (2013) to $98.4 \%$ with high quality of life. $\mathrm{MOH}$ (2006) mentioned that career path had 4 components that comprise career path, career goals, career planning and career development so that the dimensions of the quality of work life of nurses increase.

Improvement of the quality of work life of nurse on almost all of these respondents was the result of RSUP Dr. Hasan Sadikin nursing management business Bandung that already pay attention to the quality of nurse work life. This is in line with research by Rivai and Sagala (2009) that explain the quality of work life is a systematic effort of an organization to provide employees with greater opportunities to influence work and staff's contribution to the achievement of hospital goals.

Researcher argued that the quality of work life becomes an important and core of service. Where if the organization of hospitals, especially nursing can ensure nurse get a high quality of work life then the nurses will provide themselves as a whole and focus in the service. The nurse will show high loyalty and cooperation to the organization of the hospital. The nurses are also assured of being bound and possessed so that it will help the organization to achieve the organization's goals.

In work life/home life, this dimension can be defined as the relationship between the nurse life experience in his/her workplace and the life at home. Brooks \& Anderson (2005) meant that job implementation is influenced by the life of nurse at home, and vice versa. The results of the research in table 1 , on the dimensions of work life/home life appeared high, it was shown from the actual range of 18-24 with a mean of 21.86 and the middle value of 17.5.

The results of the research on table 2 for the dimension was also increase compared to the result of line based survey conducted by Susilaningsih, Kurniawan, Somantri, and Yudianto (2013) where at the actual range of 12-21 with the mean of 16.72 (low category). The increase in the distribution of respondents also experienced an increase that was originally only part of the respondents $(59 \%)$ (high category) and increase to almost entirely $(97.93 \%)$. This indicated that almost all respondents were able to balance between the fulfillment of work need with the fulfillment of life at home.

Researchers argued that this increase occurred because the organization had concerned nurse staff on aspects of life in the work environment that ultimately affect life at home. Implementation of career path that was implemented also gave a positive influence on the increase in this dimension. The organization had implemented flexible working hours and the nursing staff that had the right to apply for work or holidays. The head of the room seemed to consider the request and tried to grant the request, although not all requests were granted due to labor requirements. The culture of tolerance built between nursing staff also looks so high that each other can help so nurses were not too tired.

A 24-hour nursing service enabled the nurses to work full and divided by shift. From this dimension it appeared that nurses still have a good quality of work life because nurses had been able to manage themselves to work according to shift. The nurses seem to still had energy after work because when nurses had time off during work. Matters related to the dimensions of work life/home life causes the nurse to feel to get a better 
Ineke Patrisia : Relationship between Quality of Nursing Work Life with Nurse Job Satisfaction

quality work life so that almost all nurses can feel comfortable when returning home even while working.

In the work design dimension, this dimension can be defined as a combination of nursing work and describes the actual work performed by the nurse. Brooks and Anderson (2005) considers that the important things that should be in this dimension are staff forming and staff palcement, sharing of workload and autonomy in work. The results of the research in table 1, on the work design dimension was high, it was shown from the actual range value 25-35 with the mean value of 27.61 and the middle value of 25 . The results of this study increased compared to the result of line based survey conducted by Susilaningsih, Kurniawan, Somantri, and Yudianto (2013) where at the actual range of 15-31 with a mean of 24.29 (low category).

The increase in the distribution of respondents is also seen in Table 2 which encountered an increase that was initially only part of the respondents (52\%) (high category) and increased to almost entirely $(90.15 \%)$. It indicated that the work design dimension was good. Researcher argued that the improvement of the work design dimension is based on the clarity of the division of labor based on the clinical authority of each nurse.

Implementation of nursing career path helped the organization of hospital to be able to divide the work based on nursing career level. The division of career nurse level gave the limits in accordance with the competence and authority of each nurse, so that the nurse can be more clear in providing services. Matters related to the implementation of career path directly affected the reduce of workload due to work done in accordance with the clinical authority of each nurse. Nurses also became more independent and had enough time to complete the work so as to provide quality services to patients. And nurses would feel satisfy in working.

However, hospital nursing management should still be concerned about the workload. This is because from the interview results found that the respondents complained about the need for additional nurses who were available at their place of work. The lower number of nurses will lead to an increase in work volume as this will affect the division of labor and workload. It should be of great concern to the management of the hospital, particularly the nursing field to reconsider the need for the number of nursing personnel taking into account the characteristics of the working properties of each work unit in relation to the focus of the study, the scope of the work and the intervention base (internal disease unit and surgical unit ).

Implementation of this clinical nursing careerpath provided space for the organization to provide work in accordance with the clinical authority and competence it had in order to achieve organizational goals. Each individual had their respective duties and roles and works together, in order to achieve the stated and agreed objectives in the form of organizational vision. Group members in this case were nurses performing task roles, building groups and maintaining their individual roles as nursing service provider. so as to achieve organizational goals.

In the work context dimension, this dimension can be explained as a nurse's work practice setting and exploring the impact of the work environment on the patient and nurse system. Based on Brooks and Anderson (2005), the work context dimension is closely related to the dimension of work design, but it contains a broader aspect. The dimensions of the work context include management, supervision, relationships between colleagues and the work environment. The results of the research in table 1, on the work context dimension is high, it is shown from the actual range value 50-72 with a mean of 59.59 and the mean value of 50 .

The results of this study were both in the high category with the result of line based survey conducted by Susilaningsih, Kurniawan, Somantri, and Yudianto (2013) where at the actual range 41-74 with a mean of 59.59. The increase occurred in the distribution of respondents (table 2), which was originally only part of the respondents $(42.2 \%)$ (high category) and increased to almost entirely $(94.82 \%)$. This indicates that almost all respondents experienced an increase in the work context dimension.

Gibson (2011) said that the employee participation as a concept of applied management in developing and implementing decisions directly affects theirwork. Employee 
Ineke Patrisia : Relationship between Quality of Nursing Work Life with Nurse Job Satisfaction

engagement is part of a motivational program derived from the facilities and assumptions described by experts and supports human relations in the work environment.

Almost of all respondents also stated that they were involved in the decision making done by the supervisor. Rastegari (2010) explained that the increased involvement of nurses in the execution of care and decision making will reduce the stress of the soul, stopping from work and even absenteeism. These things can support the creation of good quality of work life. Workers will feel part of their organization if they are involved in all organizational activities.

Almost all respondents stated that they received good performance supervision and obtained feedback from supervisors. The nurses felt that with direct supervision from the supervisors the nurse could feel direct feedback and be able to ask or even gain new experiences. In addition, feedback can also be a tool to provide rewards in order to provide motivation to nurses.

Researcher viewed that almost all nurses have good interpersonal relationships with peers, superiors, supervisors, doctors, and with other health workers. This showed that a healthy work climate was realized due to a conducive working environment. Based on the results of observations during the research field, it appeared that nurses to each other related in harmony and it is also intertwined with doctors and other health workers. Rastegari (2010) stated that factors in the work environment can increase the productivity of human resources.

One of the components in this dimension is how communication has already occurred and affected collaboration on other health workers. Good communication can prevent conflicts within the organization and it can improve productivity and performance. Collaboration is necessary in the order of health services. Collaboration of nurses with other health personnel can affect the work satisfaction of nurses and will impact on improving the quality of care of health care in hospitals.

In the work world dimension, Brooks and Anderson (2005), stated that this dimension illustrates the effects of broad social environmental influencesand the effects of changes in nursing practice on the quality of nurse work life. In other words, this dimension includes about how people's perceptions of nursing professions and socio-economic conditions occur in the environment outside the workplace (Brooks \& Anderson, 2005).

The results of the research in table 1 , the dimensions of work world was high, it was shown from the actual range value 13-17 with mean value 14.31 and the mean value of 12.5. It was as high as the value of the result of line based survey conducted by Susilaningsih, Kurniawan, Somantri, and Yudianto (2013) where at the actual range of 10-20 with mean value 14.35 . The increase occurred in the distribution of respondents (table 2), which was originally only part of the respondents $(45.9 \%)$ (high category), to almost all respondents $(81.35 \%)$. This indicates that almost all respondents experienced an increase in the dimensions of work world.

The increase showed that the knowledge of the community related to the nursing profession has also increased because almost all respondents feel the increase. This is in line with Rastegari research (2010), that the level of public knowledge of the nursing profession should be improved through interviews and explained that in health services in addition to medical services, nurses also have a good and effective role. In addition, nurses must work with the media to increase knowledge of nursing roles to the community.

\section{2) Nurse Job Satisfaction}

Based on the results of research in table 4, nurse job satisfaction in Dr. Hasan Sadikin Bandung was $79.3 \%$ satisfied so that the level of nurse job satisfaction almost entirely satisfied. This indicates a correspondence between nurse expectations and the reality / experience gained. This is in accordance with a study by Colquitt et al (2010) which says that job satisfaction is a pleasant emotional as a result of job assessment and work experience. Nurses who are satisfied with their work will be visible from the way the nurse respond to their work. Nurses with positive job satisfaction experience will definitely improve performance in doing activities.

Nurse work satisfaction becomes the most 
Ineke Patrisia : Relationship between Quality of Nursing Work Life with Nurse Job Satisfaction

basic thing to be considered because it is in accordance with the theory of Maslow that states that humans have 5 basic human needs namely psychological needs, security and comfort, social, ego and self-actualization. Where the lowest needs must be met ahead of other needs. If employees are not satisfied with their work, when employees will have low motivation, so in the work they usually do not get excited and have some errors and others.

In this study still appearsed a small part $(20.7 \%)$ of nurses that were not satisfied with its their job. Some aspects that affect nurses' job satisfaction according to Robbins (2006) are related to challenging jobs, worthy income, working conditions and supportive friends. Based on the results of interviews while accompanying the questionnaire, respondents felt not satisfied with the income earned, although actually increased compared to before the implementation of nurse career level. Researchers argued that satisfaction and dissatisfaction is a subjective judgment and concerned about each individual nurse associated with the desired expectations and the reality obtained.

The results of the researcher's analysis of respondents job dissatisfaction based on individual characteristics. Individual characteristics are variables that are often analyzed in the field of behavioral organization science because these variables have an impact on job satisfaction. Psychological research on gender variables has found that men are more aggressive and more likely to have hope for success, so men tend to be more dissatisfied with their work than women. Kreitner \& Kinicki (2010) stated that the increasing of one's working year will increase of job satisfaction. Long work period will tend to make an employee or nurse feel more comfortable in an organization, such as having been adapted to the environment long enough so that an employee will feel comfortable with his job. It shows that less work will show dissatisfaction with the job.

3) Cartesian Diagram of Nurse Job Satisfaction

Primary Priority Indicator

Based on the theory that was proposed by Martilla and James (1977) in Supranto (2007), the attributes included in this quadrant should be increased and become the top priority in order to achieve total nurse job satisfaction

The indicator that lies in this quadrant is with respect to the compensation with the salary statement I receive and the work I do. Thisisinaccordance with the aspects that affect job satisfaction according to Robbins (2006) is a decent wage. Indicators in this quadrant should be the top priority of improvement for the realization of nurse job satisfaction. This is in accordance with Robbins and Judge (2006) in which a reasonable reward is the desire of all employees of the payroll system. If the salary is felt fair then there will be satisfaction. According to Mondy and Noe in Panggabean (2002) (in Robbins \& Judge (2013)), salary is a financial compensation given to workers/employees on a regular basis and is the most important award in the organization. This is in accordance with the theory of Two Factors which is the theory of Frederick Herzberg (1959) in As'ad (2003) compensation is a source of dissatisfiers/ dissatisfiers where the existence of the source of this dissatisfaction is interpreted with if these factors are not met it will bring dissatisfaction at staff. So that nursing management of Dr. Hasan Sadikin should pay attention to this indicator as a top priority in order to create nurse job satisfaction. The next indicator is working conditions with a statement of working environment conditions such as the availability of room and work equipment. This needs to be a priority because in accordance with the aspects that affect job satisfaction according to Robbins (2006) that is working conditions that support. This is supported by Robbins and Judge (2002) who mentioned the need for more modern facilities and with more adequate equipment. Nitisemito (2000) also mentions the factors that affect working conditions such as a clean environment, good ventilation, harmonious working relationships between staff, noise levels. Working conditions are an important factor in providing employee job satisfaction so that this indicator should be increased because it will increase the responsibility towards quality improvement and productivity.

Based on the theory of Two Factors which is Frederick Herzberg's theory (1959) in 
Ineke Patrisia : Relationship between Quality of Nursing Work Life with Nurse Job Satisfaction

As'ad (2003) working conditions is a source of dissatisfiers where the existence of a source of dissatisfaction is interpreted with if these factors are not met it will lead to dissatisfaction with the staff. So that nursing management of Dr. Hasan Sadikin should pay attention to this indicator as a top priority in order to create nurse job satisfaction.

Based on Theory of Work Adjustment that Dawis disclosed, Lofquist, and Weiss (1968), if an employee can have a relationship with his working environment then he will try to defend it. However, if he does not find the relationship, he will try to build that relationship and if it fails it will lead to leave the job. When an individual is able to fulfill the requirements of his or her working environment it can be regarded as a satisfactory worker, and if his or her working environment can meet an individual's needs, then he can be said to be a satisfied worker.

The third indicator is recognition with the praise statement which I get for the work done. Praise according to Winardi (2004) is a form of reward that can affect the psychological aspect and is a social award. This is in line with Mahmudi (2005) which stated that praise is an important element in the reward system is psychological and social awards. Reward is an educational tool that is easy to apply and pleases employees. Therefore, praise is necessary to generate employee motivation. Management of Dr. Hasan Sadikin Bandung should prioritize this because this is in accordance with the theory of two factors Herzberg in As'ad (2003) which divides 2 categories based on the characteristics of one of the categories Motivators. Under this category, it is important for management to provide recognition by praising the performance that has been done. If praise is given it will form a strong motivation so that the quality of work becomes better. Motivator factors are also a source of job satisfaction so that when prioritized by the organization it will lead to job satisfaction.

The last indicator in this quadrant is independence with an opportunity statement to try my own method of doing the job. This is in accordance with Robbins (2006) about the aspects that affect job satisfaction is a challenging job. One of the challenging job indicators is a job that provides an opportunity to use the knowledge, skills and skill that is in the employee. Hackman and Oldham (1980) mentions that there is an autonomy dimension to that aspect in which employees have the freedom to be able to use the working methods to be used. Freedom given to employees will enable employees to explore themselves and show initiatives to do their own work to the end.

\section{Indicators that Need to be Maintained}

Based on the theory put forward by Martilla and James (1977) in Supranto (2007), quadrant $B$ shows the factors that are considered very important that have been successfully implemented according to the wish/ expectation of the nurse and very satisfying (high satisfaction) so it must be maintained. The indicator that lies in this quadrant is with respect to supervision technical with the statement of my supervisor's competence in making decisions.

This is in accordance with Herzberg's Two Factor theory (1959) in As'ad (2003), the Hygiene Factors category which is a factor that proves to be a source of dissatisfaction eg supervision technical such as decision making and other technical related matters whose existence affects satisfaction. So the organization of hospitals must pay attention and maintain that there is no dissatisfaction. This factor appears to be in accordance with the wishes of nurses and has been done by the organization so that must be maintained.

The next indicator of moral values with the statement is able to do things that are not contrary to my conscience. According to Weiss, Dawis, England, Loqfuist (in Vidiasta, 2010), moral values are an intrinsic dimension which, when considered, lead to job satisfaction in employees. This is in accordance with Motivator Factor on Herzberg's Two Factor Theory (The Factor Theory) in As'ad (2003) which will increase the nurse's job satisfaction because the individual feels doing things that are not against his conscience.

Another indicator is advancement with an opportunity statement for progress on the job. This indicator is important to maintain because this indicator conforms to the theory of Two Factors which is Frederick Herzberg's 
Ineke Patrisia : Relationship between Quality of Nursing Work Life with Nurse Job Satisfaction

theory (1959) in As'ad (2003). Where the source of job satisfaction/motivators category/satisfiers which if this factor exists and maintained it will form a job satisfaction that give rise to a strong motivation so that the quality of work becomes better. This advancement itself is related to nurse career development which has been supported by the implementation of nurse career clinic. Therefore, the implementation of the nurse career clinic in path must be maintained to maintain the nurse job satisfaction.

Another indicator is co workers with relationship statements interact with colleagues. This is important to be maintained by the organization of hospital because according to Robbins (2006), supportive colleagues is an important aspect to achieve job satisfaction nurse.

The last indicator in this quadrant is the responsibility with the statement of freedom using self-assessment. In this indicator the nurse must remain responsible with the nursing services provided. This indicator is important to maintain because this indicator is in line to the theory of Two Factors which is Frederick Herzberg's theory (1959) in As'ad (2003). Where is the source of job satisfaction / motivators category/satisfiers which if this factor exists and maintained it will form a job satisfaction that gave rise to a strong motivation so that the quality of work for the better.

4) The relationship between quality of nurse work life with nurse job satisfaction

Brooks and Anderson (2005) stated that the quality of work life is a concept that describes the perception and view of the nurses that will fulfill their life needs through work experience in the organization so that nurses can have maximum productivity and get personal satisfaction on the fulfillment of their needs. Job satisfaction of the nurse according to Colquitt et al. (2010) is emotionally pleasurable as a result of job assessment and work experience. So in other words describes a person's feelings towards his work. Employees with positive job satisfaction experience will improve performance in their activities and vice versa. Mullin in Wijono (2010) said that the role of the organization affects employee satisfaction so that in this case the role of the organization is very important in maintaining the quality of nurse job which can improve the satisfaction of each individual nursing staff.

The results of this research indicated that both variables have a significant relationship and direction. This is in line with the study which was conduted by Zulkarnain (2011) that a positive relationship between the quality of nurse work life with job satisfaction would show favorable conditions between the nurses staff and the organization. The results of a positive quality of work life will show an increase in job satisfaction. It is also in line with research by Marlinda and Turnip (2017) which revealed that there is a positive and significant relationship between quality of work life and job satisfaction. In the research was mentioned that the application of good quality of work life will increase the work satisfaction of his staff. Similar opinion expressed by Dipodjoyo (2015) said that there is a significant relationship with the positive direction between the quality of work life with job satisfaction. It appears that the higher the quality of work life will be the higher the employee job satisfaction.

This is in accordance with the research of Sudarsono (2007) which states that job satisfaction is significantly positively correlated to QWL. The higher a person's job satisfaction the higher the QWL. We believe that the quality of the nurse's work life supports a hospital to apply a process that is sensitive to the needs of its staff and provides nurse staff the opportunity to plan their own working lives. This is supported by Hadi (2008) which stated that the quality of work life intended as an organizational strategy that manifests and maintains staff work satisfaction with the aim of improving the working conditions of individuals and organizations and benefits for employers.

Individuals will feel useful and have a stake in the organization, communication will be well established between the leadership and staff even with colleagues so that it will create job satisfaction. Job satisfaction itself is individual and will certainly differ from one individual to another. Job satisfaction is very important because it will lead them to the improvement of attitude and work behavior. 
Ineke Patrisia : Relationship between Quality of Nursing Work Life with Nurse Job Satisfaction

Therefore, every organization, especially nursing management of a hospital must really understand the job satisfaction of each of its staff to improve the behavior of its staff in working. If an organization does not pay attention to the quality of work life, the nurse job satisfaction will not happen. And will create adverse situations and conditions for the organized life and individual staff itself such as the decrease in nurse productivity, so as to provide nursing services that are not optimal to the patient. Another possible condition is the desire of the nurse to leave the hospital which may disturb the stability of the service because the service provider's resources are reduced.

When looking at the correlation coefficients, these two variables had a weak relationship (0.246). It can be seen from tables 2 and 4, where there were unequal number of respondents who have high quality of nurse work life $(98.4 \%)$ and nurse job satisfaction $(79.3 \%)$. Therefore, the management of Nursing Hospital must fix the things that become the main priority to achieve nurse job satisfaction. The staff of the nurse must obtain fair and reasonable compensation, for it is necessary to prepare and administer a system and structure of direct and indirect compensation that were competitive and could prosper the life of the employees according to position in the organization and socioeconomic status in society.

Both variables must be addressed together in order to obtain favorable results for the organization and each individual nursing staff.

Improvement had been done by Dr. Hasan Sadikin since 3 years ago with the holding of action research (implementation of nurse career clinical system). The results that seem to increase from the quality of work life in the current line based survey and research, should be used as motivational materials RS to further refine the system.

\section{Conclusion}

The conclusions that can be drawn from the results above and discussion are: Quality of nurses work life at Dr. Hasan Sadikin Bandung had a high quality (average value above the middle value (105)) as much as 98.4\% (190 respondents), Nurse job satisfaction at Dr. Hasan Sadikin Bandung was quite satisfied as much as $79.3 \%$ (153 respondents), Indicators in the nurse's job satisfaction were the main priorities in the aspects of compensation, working conditions, praise, independence. Indicators that need to be maintained by the management of Dr. Hasan Sadikin Bandung namely technical supervision, moral values, responsibility, progress of work, co-workers, The relationship between quality of nurse work life with nurse job satisfaction was weak, significant and in line with pilot project of nurse clinical career in Dr. Hasan Sadikin Bandung.

\section{References}

As'ad. (2003). Kepemimpinan Efektif Dalam Perusahaan Edisi 2. Yogyakarta: Liberty.

Brooks, B. A., \& Anderson, M. A. (2005). Defining Quality of Nursing Work Life. Nursing Economics, 23(6), 319-326.

Cascio, Wayne F. (2008). Managing Human Resources, Productivity, Quality of Work Life, Profits. New York: Mc. Graw Hill. Inc.

Colquitt, et al. (2010). Organizational Behavior. New York: McGraw-Hill.

Depkes. (2006). Pedoman Penyelenggaraan Jenjang Karir Profesional Perawat. Jakarta: Direktorat Bina Pelayanan Keperawatan Direktorat Jendral Bina Pelayanan Medik Departemen Kesehatan RI.

Dawis, R. V., Lofquist, L. H., \& Weiss, D. J. 1968. A Theory of Work Adjustment (a revision). (Minnesota Studies in Vocational Rehabilitation, 95 Whole No. 23). Minneapolis: Univ. Of Minnesota, Industrial Relations Center.

Dipodjoyo, G. U. (2015). Hubungan antara kualitas kehidupan kerja dan kepuasan kerja dengan Phychological Well-Being pada karyawan perusahaan "ABC" Tangerang. Seminar Psikologi \& Kemanusiaan (hal. 136-140). Psychology Forum UMM. 
Ineke Patrisia : Relationshipbetween Quality of Nursing Work Life with Nurse Job Satisfaction

Gibson, J. (2011). Organizations: Behavior, Structure, Processes. [Kindle Edition]. Business and Economics Kindle Edition.

Hackman, J., \& Oldham, G. (1980). Work Redesign. Addison: Wesley Publishing Company.

Hadi, A. (2008). Pengaruh Kualitas Kehidupan Kerja dan Ko mitme n Organisasional terhadap Kinerja Pegawai di PT. Bank Jabar Banten. Bandung: Program Magister Manajemen Pasca Sarjana UNPAD.

Kreitner, R., \& Kinicki, A. (2010). Organizational Behavior. Yogyakarta: Andi Offset.

Mahmudi. (2005). Manajemen Kinerja Sektor Publik. Yogyakarta: UPP AMP YKPN.

Marlinda \& Turnip. (2017). Hubungan antara kualitas kehidupan kerja dan Organizational Citizenship Behavior dengan Produktivitas Kerja Karyawan. [Skripsi]. Analitika. Universitas Medan Area. Retrieved from http://www.ojs.uma.ac.id/index.php/ analitika/article/view/776.

Nitisemito, A. (2000). Manajemen Personalia (Cetakan ke 7). Jakarta: Ghalia.

Peraturan Presiden Republik Indonesia Nomor 8 Tahun 2012 Tentang Kerangka Kualifikasi Nasional Indonesia. Jakarta: Menteri Hukum dan Hak Asasi Manusia Republik Indonesia.

Rastegari, M., Khani, A., Ghalriz, P., \& Eslamian, J. (2010). Evaluation of quality of working life and its association with job performance of the nurses. IJNMR 15(4), 224-228.

Rivai \& Sagala. (2009). Manajemen Sumber Daya Manusia untuk Perusahaan. Jakarta: PT Raja Grafindo Persada.

Robbins, S. (2006). Perilaku Organisasi Edisi Kesepuluh. Jakarta: PT. Index Gramedia.

Jakarta: PT. Index.
Robbins, S. P., \& Judge, T. A. (2013). Organizational Behavioral, 15th Edition. Pearson Education.

RSHS. (2011). Profil Rumah Sakit Dr. Hasan Sadikin Bandung. Dipetik September 6, 2016, dari http://profilrumahsakit.blogspot. com/20 11/0/rumah-sakit-hasan-sadikin.html

Sudarsono(2007).Analisa struktural equation (SEM) pada sikap hidup danpekerjaan PNS di pemerintah. Kabupaten Trenggalek. ITS Library: Ebursa.depdiknas.go.id.

Supranto. (2007). Pengukuran Tingkat Kepuasan Pelanggan Untuk Menaikkan Pangsa Pasar. Bandung: P T . Rineka Cipta.

Susilaningsih, F. S., Kurniawan, T., Somantri, I., \& Yudianto, K. (2013). Gambaran Quality of Work Life Perawat, Quality of Care dan Kepuasan Pasien Pra Implementasi Pola Jenjang Karir Perawat di Rumah Sakit Pendidikan. Bandung: Bagian Keperawatan Dasar Fakultas Keperawatan UNPAD.

Oyoh, Somantri \& Yudianto. (2017). Kualitas Kehidupan Kerja Perawat di Puskesmas Pangandaran. Jurnal Keperawatan Padjajaran, 5(3), 289-296.

Vidiasta. (2010). Hubungan kepuasan kerja dengan komitmen organisasional karyawan tetap non-manajerial PT Aero Systems Indonesia. [Skripsi]. Administrasi Niaga. Universitas Indonesia. Retrieved from http://lib.ui.ac.id/file?file=digital/132038SKNIA0102010 Vidh-Hubungan \%20 kepuasan-HA.pdf.

Wijono. (2010). Psikologi Industri dan Organisasi dalam suatu Bidang Gerak Psikologi Sumber Daya Manusia Ed. 1. Jakarta: Kencana.

Zulkarnain. (2011). Dampak Burn-out terhadap Kualitas Kehidupan Bekerja pada Pekerja Public Service. Prosiding Seminar Ilmiah Dies Natalis USU ke 50 (SI-Dies 2011), 338-345. 